\title{
IAMJ
}

INTERNATIONAL

AYURVEDIC

MEDICAL JOURNAL

ISSN: 2320-5091

Impact Factor: 6.719

\section{A VIEW OF AYURVEDA ON AUTISM SPECTRUM DISORDERS - A CONCEPTUAL STUDY}

\section{Nithya A K ${ }^{1}$, Jithesh Chowta ${ }^{2}$}

${ }^{1}$ Final year PG Scholar, Dept. of Kaumarabhritya, Alva's Ayurveda Medical College, Moodbidri, Karnataka, India

${ }^{2}$ Assistant professor, Dept. of Kaumarabhritya, Alva's Ayurveda Medical College, Moodbidri, Karnataka, India

Corresponding Author: drnithyaak89@gmail.com

https://doi.org/10.46607/iamj1509072021

(Published Online: July 2021)

Open Access

(C) International Ayurvedic Medical Journal, India 2021

Article Received: 12/06/2021 - Peer Reviewed: 15/06/2021 - Accepted for Publication: 18/06/2021

\section{Check for updates}

\section{ABSTRACT}

Autism Spectrum Disorders (ASD) is a neuro-developmental disorder. It is defined by deficits in social reciprocity and communication and by unusual restricted, repetitive behavior ${ }^{1}$ It is one of the challenging disorders for children and their families. Prevalence estimates for autism spectrum disorder (ASD) have been increasing over the past few decades, with estimates at about 5 in10,000 in the 1960s and current estimates as high as 1 in $88 .^{2}$ It is one of the challenging disorders for children and their families and this condition typically persists throughout one's life period. While coming to the view from Ayurveda, most clinical features of different varieties of autism spectrum disorder resemble the features of Unmada. The condition may be due to the result of Khavaigunya of Srotas which nurtures Manas as a consequence of many Agantuja and Sahaja factors. ${ }^{3}$

Keywords: Autism Spectrum Disorders, Unmada, Manovaha srotas, Jnanotpatti

\section{INTRODUCTION}

Autism Spectrum Disorders (ASD) is a neurodevelopmental disorder, having a previous nomencla- ture of Pervasive Developmental Disorders in DSM-

4. The researcher has shown a tenfold increase in Au- 
tism cases over the past decade. It may be higher in immigrant populations. The male: female ratio is estimated to be 4:1. Epidemiological data estimate the global prevalence of ASD has been increasing over the past few decades. It is to be one person in 160 , accounting for more than 7.6 million disabilityadjusted life years and $0.3 \%$ of the global burden of disease. ${ }^{4}$ It is the world's third most common developmental disorder, so to spread awareness every year 2nd April is marked as Worlds Autism Day.

The features of Autism are much similar to that of Unmadam. Due to various etiological factors, the conjunction between Atma and Manas is disrupted resulting in the vitiation of Manovaha srotas. Along with this, the vitiation of three doshas Vata, Pitta, and Kapha will end up in the manifestation of Unmada. ${ }^{5}$ Manovaha sroto-dushti together with Tridosha dusti is the basic cause of Childhood Autism.

\section{The word 'Autism}

The word "Autism" comes from the combination of the Greek words "auto" meaning "self" and "ism" meaning "the act, state, or theory of". The word 'Autism' initially was linked to detachment from reality in individuals with schizophrenia.

\section{ETIOLOGY OF AUTISM}

There is no well-known single cause for autism spectrum disorder, but studies suggest that genetic and environmental factors are the possible role for causing ASD.

1. Neurotransmitter abnormalities

2. Metabolic factors

3. Genetic factors

4. Environmental factors

5. Involvement of the immune system

6. Structural and functional changes in the brain

\section{Neurotransmitter abnormalities}

Some studies are characterizing the neurotransmitter, Serotonin involves in Autism and serotonin metabolism is affecting by genetic factors. For neurogenesis i.e., the formation of new neurons in the brain, serotonin plays a significant role. ${ }^{6}$

\section{Metabolic abnormalities}

In the pathology of Autism, there will be an Association of amino acids and organic acids, Krebs cycle analogues, melatonin, cyclic AMP, gangliosides, endorphins, lactate/pyruvate, glial fibrillary acidic protein and catecholamines have been studied. ${ }^{7}$

\section{Genetic factors}

With identical (monozygotic) twins, if one is autistic, the likelihood that the other twin may have some form of Autism is $90 \%$. In great contrast, for fraternal (dizygotic) twins, the likelihood that the other twin will have a form of Autism is only $2-3 \%{ }^{8}$

\section{Immune factors}

Maternal immune response, prenatal infection and altered immune responses in children with ASD are the prime focus of this study. The epidemiologic studies suggested that Progeny of women with a history of a viral or bacterial infection during the gestational period are said to be at increased risk of ASD. ${ }^{9}$

\section{Environmental factors}

Environmental factors cause an increased risk of Autism, and it is a burning topic of research. Few are quoted below.

- Lead and mercury poisoning

- Exposure to valproic acid or thalidomide very early in pregnancy

- Maternal alcohol consumption ${ }^{10}$

\section{CLASSIFICATION OF ASD}

According to the Diagnostic and Statistical Manual of Mental Disorders (DSM) IV (1994) and IV TR (2004), Autism and related disorders were collected under an umbrella of PDD - Pervasive Developmental Disorders (DSM-IV, 2000). ${ }^{11}$

\section{Classic Autism}

People with classic Autism develop language delay or have difficulties in talking with other people or lack of affection or emotional contact with others and concentrated wish for the sameness in routines, muteness or abnormality of speech, high level of Visio -spacial skills but major learning disabilities in another area.

\section{Asperger's syndrome}

Children diagnosed with Asperger's Disorder (AD) have difficulty in social interaction, reciprocity and communication. In comparison to autistic disorder, there is no significant general delay in language for diagnosed children with AD. 


\section{Childhood Disintegrative Disorders}

Childhood disintegrative disorders include severe reversion in communication skills. In the beginning, these children seem perfectly normal. They start to regress between ages 2-4 years.

\section{Rett Syndrome}

Rett syndrome is a neurological and developmental disorder that mostly occurs in females and is manifest by poor head growth. Loss of muscle tone is usually the first sign.

\section{Pervasive Developmental Disorders -Not Other} Specified

Children with PDDNOS either do not fully meet the criteria of symptoms used to diagnose any of the four specific types above and or do not have the degree of impairment described in any of the above four specific types.

Table 1: Clinical features of ASD

\begin{tabular}{|c|c|}
\hline $\begin{array}{l}\text { Social Communication and Interac- } \\
\text { tion Skills }{ }^{12}\end{array}$ & $\begin{array}{l}\text { - Avoids or does not keep eye contact. } \\
\text { - Does not respond to name by } 9 \text { months of age. } \\
\text { - } \text { moes not show facial expressions like happy, sad, angry, and surprised by } 9 \\
\text { - Does not play simple interactive games like pat-a-cake by } 12 \text { months of age. } \\
\text { - Uses few or no gestures by } 12 \text { months of age (e.g., does not wave goodbye) } \\
\text { - Does not share interests with others (e.g., shows you an object that he or she } \\
\text { - } \text { likes by } 15 \text { months of age) } \\
\text { - Does not point or look at what you point to by } 18 \text { months of age. } \\
\text { - Does not notice when others are hurt or sad by } 24 \text { months of age. } \\
\text { - } \text { age) } \\
\text { - Hhows little interest in peers. } \\
\text { - } \text { at } 36 \text { months of age or older. } \\
\text { Does not play games with turn-taking by } 60 \text { months of age }\end{array}$ \\
\hline $\begin{array}{l}\text { Restricted or Repetitive Behaviors or } \\
\text { Interests }\end{array}$ & $\begin{array}{l}\text { - Other objects and gets upset when order is changed. } \\
\text { - Repeats words or phrases over and over (i.e., echolalia) } \\
\text { - } \text { Plays with toys the same way every time. } \\
\text { - Is focused on parts of objects (e.g., wheels) } \\
\text { - Gets upset by minor changes. } \\
\text { - Has obsessive interests. } \\
\text { - } \text { Must follow certain routines. } \\
\text { - Has unusual reactions to the way things sound, smell, taste, look or feel }\end{array}$ \\
\hline Other Characteristics & 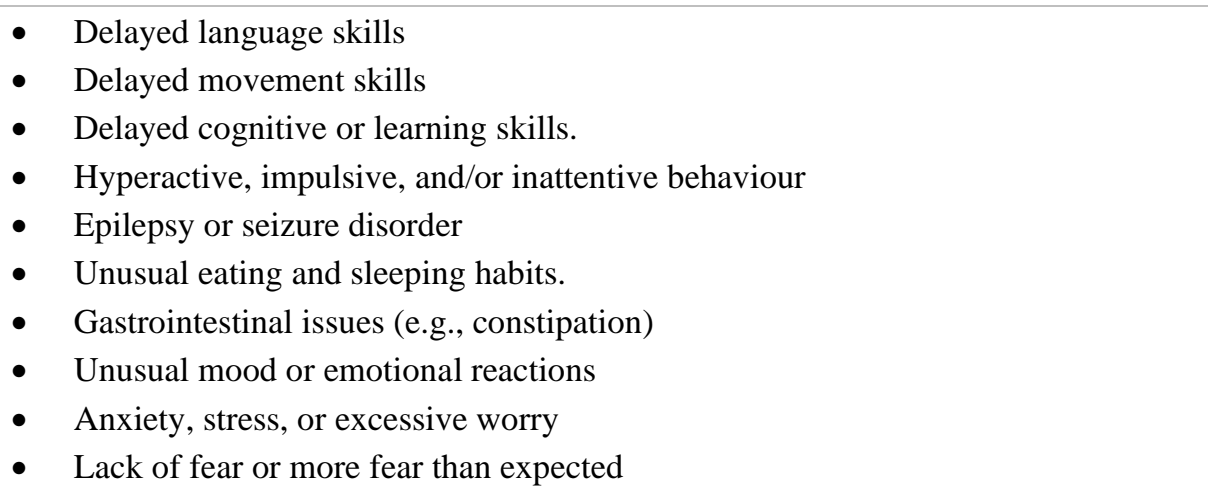 \\
\hline
\end{tabular}




\section{ASD SCREENING, DIAGNOSIS, AND AS- SESSMENT}

Diagnosis of ASD is based on clinical history followed by observing and interacting with the child. There are no specific clinical markers or laboratory tests that can be used to diagnose autism. However, there are various standardized checklists, assessment tools, and criteria that are used to make a diagnosis of ASD. ${ }^{13}$

\section{Screening checklists}

- M-CHAT is an easy to administer checklist for screening of autism and the Indian Scale for Assessment of Autism is a scale developed for Indian children.

Diagnostic tools: Autism Diagnostic Observational Schedule is the gold standard diagnostic tool.

- Autism Diagnostic Interview-Revised

- Childhood Autism Rating Scale

- INCLEN Diagnostic Tool for Autism (INDTASD): An Indian tool to diagnose autism.

\section{STANDARD APPROACHES}

Occupational therapy: Occupational therapy employs a variety of strategies to help a child with $\mathrm{Au}-$ tism participate more effectively in everyday tasks. It helps strengthen certain areas like gross motor skills and fine motor skills.

- Speech therapy: Speech therapists work with the child and help improve communication. They use alternate methods like gestures, picture boards, etc. to help the child learn how to express their thoughts and ideas to others. It is important to have speech therapy as part of an interdisciplinary intervention programme because children with Autism have more trouble in communication.

- Sensory integration therapy: Helps the child deal with sensory information such as sights, sounds and smells. Sensory integration therapy could help a child who is bothered by certain sounds or does not like to be touched.

\section{Other approaches}

- Music therapy: For children with ASD, music therapy employs specific musical activities to improve social and communication skills in children with Autism.
- Picture Exchange Communication System (PECS): This is used commonly for children with Autism who have minimal or no communication abilities. Picture symbols or cards are used to facilitate communication.

\section{- Play therapy}

Play is regarded as a natural medium for selfexpression.it provides an opportunity for the child to play out of his feelings as well as problems. In autistic children, the directive play therapy provides ample opportunities for the child to mature in the right direction.

\section{UNDERSTANDING ASD IN AYURVEDA}

For determines the process of cognition and by getting a generation of knowledge - Jnana there will be a Sequential association of Indriya, Indriyārtha, Manas and Atma. Indriya (sense organs) receive its corresponding Artha when stimulated by the Manas (sensory perception). This sensation is further screened by Manas (determination) ie the mental faculty and it is at this stage, Smrti is developed as a part of cognition, which is refined to Budhi or intellect and finally stored in Atma, the final abode of knowledge. ${ }^{14}$ Imprint or Smrti is the product of a well-coordinated cognitive process. Any derangement in this sequence results in deranged behavioural and emotional responses and the person remains unfit to the social fabric. In short, the disruption in the cognitive process is the cause of all behavioural and communicative issues in ASD. The product of Jnanotpatti kramam - Smrti which further gets refined as Jnana is also affected in this case.

\section{Jnanotpatti Karma}

Social stimulus he receives from socialization for a normal being, he undergoes this Jnanotpatti Kramam and Jnana when a stimulus is generated. ${ }^{15}$ This knowledge further helps him to respond in every further situation simulating this. In children with $\mathrm{Au}$ tism, these social stimuli fail to pass. So, a wellcoordinated Jnanotpatti Kramam by Jnana is not developed. Thus, when he gets exposed to the very same stimuli in another situation, he fails to have a socially fit response; he is marked odd in the social fabric and diagnosed autistically. This discord is the 
causative factor behind social and behavioural deficits in Autism. This is what happens in the case of the patho- psychology of unmada. ${ }^{16}$

\section{NIRUKTHI}

- Mano vibhramam: Mental confusion - loss of social orientation and all behavioural issues in Autism

- Budhi vibhramam: Impaired intelligence - communication, learning and cognitive issues in $\mathrm{Au}-$ tism.

- Samjna jnana vibhramam: Impaired consciousness

- Smrti vibhramam: Impaired memory

- Bhakti vibhramam: Loss of desire, loss of innate quality of self-realization

- Sila vibhramam: Inappropriate manners and behaviours, repetitive behaviour and restricted behaviour
- Chesta vibhramam: Motor clumsiness and motor stereotypies

- Achara vibhramam: Loss of skills, inability to follow commands, lack of socialization.

\section{Understanding the pathophysiology of Autism}

Srotas are the channels that are responsible for Dosha GamanaDhatu Pusti and Mana Sudhi in these channels cause derangements and are responsible for various physiological anneurological disabilities. A possible cause of Autism may be Khavaigunya as consequence of many Agantuja and Sahaja factors and further vitiated Doshas may exacerbate the Khavaigunya leading to various core features of Autism. The nearest similarity of Autism with Ayurvedic diagnosis is Unmada (Insanity). The Lakshanas (features) described in Unmada with are a mixture of features of Vata, Pitta \& Kapha singularly or collectively are even seen in Autism. ${ }^{17}$

Table 2: Features of Unmada correlated with ASD/PDD

\begin{tabular}{|c|c|c|c|}
\hline Features of vatajonmada & & Features of ASD / PDD & Type of ASD / PDD \\
\hline $\begin{array}{l}\text { Parisaranam } \\
\text { Ajasra }\end{array}$ & $\begin{array}{l}\text { Always running } \\
\text { around }\end{array}$ & Hyperactive & Childhood Autism \\
\hline $\begin{array}{l}\text { Akasmat akshi bhru } \\
\text { oshța amsa hanu } \\
\text { agrahasta pada anga } \\
\text { vikshepana }\end{array}$ & $\begin{array}{l}\text { Repeated movements } \\
\text { of eyebrows, lips, } \\
\text { chin hands feet and } \\
\text { other organs }\end{array}$ & $\begin{array}{l}\text { Highly repetitive and } \\
\text { stereotyped hand and } \\
\text { eye movements }\end{array}$ & Childhood Autism \\
\hline $\begin{array}{l}\text { Satatam aniyatanam } \\
\text { ca giram utsargah }\end{array}$ & $\begin{array}{l}\text { Frequent utterance of } \\
\text { uncontrolled sound } \\
\text { and voice }\end{array}$ & $\begin{array}{l}\text { Monotonous speech, } \\
\text { oddity in speech }\end{array}$ & Asperger syndrome \\
\hline Phenaagamam Asya & Drooping of saliva & Drooping of saliva & Rett syndrome \\
\hline $\begin{array}{l}\text { Abhikshna } \\
\text { Smita hasita nrutya } \\
\text { gita vaditra } \\
\text { samprayogasca } \\
\text { asthane }\end{array}$ & $\begin{array}{l}\text { Excessive screaming, } \\
\text { dancing, singing. } \\
\text { using musical } \\
\text { instruments at } \\
\text { improper places }\end{array}$ & $\begin{array}{l}\text { Fond of music etc } \\
\text { Screaming without } \\
\text { any cause }\end{array}$ & $\begin{array}{l}\text { Autism } \\
\text { Asperger syndrome }\end{array}$ \\
\hline $\begin{array}{l}\text { Vina vansa sankhasamyatala } \\
\text { sabdanukarañam }\end{array}$ & $\begin{array}{l}\text { Mimicking vinga, flute } \\
\text { Etc }\end{array}$ & Echolalia & $\begin{array}{l}\text { Autism } \\
\text { Asperger syndrome }\end{array}$ \\
\hline Yanam ayānaih & $\begin{array}{l}\text { Riding on nonvehicle } \\
\text { toys etc. }\end{array}$ & $\begin{array}{l}\text { Riding on nonvehicle } \\
\text { toys etc. }\end{array}$ & Autism \\
\hline $\begin{array}{l}\text { Alankaraņam } \\
\text { analnkarikair } \\
\text { dravy air }\end{array}$ & $\begin{array}{l}\text { Ornamentation with } \\
\text { non-ornamentals }\end{array}$ & $\begin{array}{l}\text { Ornamentation with } \\
\text { non-ornamentals }\end{array}$ & Autism \\
\hline $\begin{array}{l}\text { Abhyavahareşu } \\
\text { avalabdheshu } \\
\text { lobhacha }\end{array}$ & $\begin{array}{l}\text { The desire for rare edible } \\
\text { food materials }\end{array}$ & $\begin{array}{l}\text { Eating disorder } \\
\text { Selective eating }\end{array}$ & $\begin{array}{l}\text { Autism } \\
\text { Asperger syndrome }\end{array}$ \\
\hline
\end{tabular}




\begin{tabular}{|c|c|c|c|}
\hline Features of paittikonmādam & & Features of ASD / PDD & Type of ASD / PDD \\
\hline Amarsha & $\begin{array}{l}\text { Intolerance, } \\
\text { Impatient }\end{array}$ & $\begin{array}{l}\text { Reluctance or } \\
\text { impatience for turn } \\
\text { talking }\end{array}$ & $\begin{array}{l}\text { Autism } \\
\text { Asperger syndrome }\end{array}$ \\
\hline Krodha & Anger & Temper tantrums & $\begin{array}{l}\text { Autism } \\
\text { Asperger syndrome }\end{array}$ \\
\hline $\begin{array}{l}\text { Asthane } \\
\text { Samrambha }\end{array}$ & $\begin{array}{l}\text { Violence or } \\
\text { aggression at } \\
\text { improper situations }\end{array}$ & $\begin{array}{l}\text { Violence or } \\
\text { aggression at } \\
\text { improper situations }\end{array}$ & Asperger syndrome \\
\hline $\begin{array}{l}\text { shastra loshtra kasha } \\
\text { kashtha mushtibhir } \\
\text { abhihananam } \\
\text { paresamm va }\end{array}$ & $\begin{array}{l}\text { Makes self-injuries. } \\
\text { by hiking arrows } \\
\text { wood or fist }\end{array}$ & Self-injury & $\begin{array}{l}\text { Autism } \\
\text { Asperger syndrome }\end{array}$ \\
\hline Abhidravaņam & Attacking & Attacking & $\begin{array}{l}\text { Severe Autism } \\
\text { Asperger syndrome }\end{array}$ \\
\hline $\begin{array}{l}\text { Prachayasitodaka } \\
\text { Annabhilasha }\end{array}$ & $\begin{array}{l}\text { The desire for cold food } \\
\text { and water }\end{array}$ & $\begin{array}{l}\text { The desire for cold food } \\
\text { and water }\end{array}$ & $\begin{array}{l}\text { Autism } \\
\text { Asperger syndrome }\end{array}$ \\
\hline $\begin{array}{l}\text { Santapam ca } \\
\text { Atirekam }\end{array}$ & $\begin{array}{l}\text { Excessive heat or } \\
\text { Anguish }\end{array}$ & Excessive distressed & $\begin{array}{l}\text { Autism } \\
\text { Asperger syndrome }\end{array}$ \\
\hline
\end{tabular}

Table 3: Clinical features of Autism \& their relationship with Dosha ${ }^{18}$

\begin{tabular}{|c|c|c|c|}
\hline $\begin{array}{l}\text { Features of kapha- } \\
\text { jonmada }\end{array}$ & & $\begin{array}{l}\text { Features of ASD / } \\
\text { PDD }\end{array}$ & Type of ASD / PDD \\
\hline Ekadese sthanam & $\begin{array}{l}\text { Stay in one place or } \\
\text { Spot }\end{array}$ & Solitary play & Childhood Autism \\
\hline Tūşnฺimbhāovah & Silence, less talkative & $\begin{array}{l}\text { Less babbling and } \\
\text { speech along with } \\
\text { gestures }\end{array}$ & Childhood Autism \\
\hline $\begin{array}{l}\text { Alpaśah } \\
\text { Camkramañam }\end{array}$ & $\begin{array}{l}\text { Clumsiness, less } \\
\text { Mobility }\end{array}$ & $\begin{array}{l}\text { Clumsiness, less } \\
\text { Mobility }\end{array}$ & Asperger syndrome \\
\hline $\begin{array}{l}\text { Lalā śinghāṇaka } \\
\text { Sravañam }\end{array}$ & $\begin{array}{l}\text { Drooling of saliva, } \\
\text { running nose }\end{array}$ & $\begin{array}{l}\text { Drooling of saliva, } \\
\text { running nose }\end{array}$ & $\begin{array}{l}\text { Organic pathologies } \\
\text { with autistic features }\end{array}$ \\
\hline Anannābhilāşa & $\begin{array}{l}\text { Aversion towards } \\
\text { Food }\end{array}$ & Eating disorder & Childhood Autism \\
\hline Rahah kāmatā & Liming for loneliness & Show less attention & Childhood Autism \\
\hline
\end{tabular}

\begin{tabular}{|l|l|l|}
\hline \multirow{4}{*}{$\begin{array}{l}\text { communication } \\
\text { features }\end{array}$} & Clinical features & Dosha \\
\hline \multirow{3}{*}{ Social features } & The problem in verbal and non-verbal communication & vata \\
\cline { 2 - 3 } & Inability to engage socially or emotionally with caregivers & vata \\
\cline { 2 - 3 } & Preference for solitary play & vata \\
\hline & Poor eye contact & vata \\
\hline & Delay of speech and language & vata \\
\hline & Impairment in comprehension and language & vata \\
\hline & Fluent but unintelligible jargon & vata \\
\hline & Irritable & vata \\
\hline & Chronically unhappy & vata \\
\hline
\end{tabular}




\begin{tabular}{|c|c|c|}
\hline & In some cases, hyperactivity and impulsivity & vata \\
\hline & Stereotypical body movements & vata \\
\hline & Behaving like deaf & \\
\hline \multirow[t]{4}{*}{ Mental features } & Neurological dysfunction like seizures & vata \\
\hline & Few children showing amazing remarkable talent & Vata kapha \\
\hline & Mental retardation in $50-70 \%$ cases & vata \\
\hline & Sleep disturbance & vata \\
\hline
\end{tabular}

\section{CHIKITSA}

In Ayurveda, Dhee Dhairya Atmadi Vijnam Manoaoushodhamparam. So, for that the main treatment is proper counselling and use specific Medhya rasayanas advocated. ${ }^{19}$

\section{Yuktivyapashraya chikitsa}

Different types of internal medication especially agni deepaaka dravyas, Ghrita preparations, medhya drugs and external procedures like Nasya, Dhupanas, Dhoompanas, Shiropichu tailam and shiro abhyanga to reduce symptoms should be adopted.

\section{Daivayapashraya chikitsa}

Ayurveda uses various psychological measures for getting the desired effect of a therapy or condition not responding to treatment. This comprises of chanting of hymn, offerings etc.

All this practice acts at the psychological level.

\section{Satvavajaya chikitsa}

This includes behaviour therapy which helps to control senses from harmful objects and controlling temper tantrum. Apart from that Medhya and Vatahara drugs should aim to correction of maladaptive behaviour.

\section{Specific treatment}

In Ayurveda, various remedies have been described by Acharyas to correct cognitive, adaptive behaviour functions and memory.

\section{DISCUSSION}

Even though the condition has not been mentioned directly in Ayurveda, similar features suggesting Autism has been described. The exact cause of Autism is still not known, genetic factors (Beeja Dosha) and antenatal and postnatal factors may affect this disease. Prajnaparadha by the pregnant mother is another cause because it may lead to Manovikara in the neonate which results in the appearance of the signs of autistic spectrum disorders at a later period. Vata Dosha is a prime factor responsible for the neurological as well physiological functions of the body, all the above-observed causes lead to Dushti of Vata which is the most important reason in developing the features of Autism.

\section{CONCLUSION}

Ayurveda opens a large door in the management of Autism and similar condition and shows the ray of hope to those in dark. Symptoms of unmada seem to be the most appropriate correlation after understanding this disorder from the Ayurveda aspect. Considering Vata Dushti as a prime reason for causing the disease, treatment must be planned according to the child's ability to tolerate the same and towards normalizing the Vata Dosha. However, Ayurveda advocates prevention of these types of conditions as a more beneficial measure than managing them.

\section{REFERENCES}

1. A Parthasarathy. IAP Textbook of Paediatrics $4^{\text {th }}$ edition 2009 Vol. II Jaypee Brothers Medical Publisher New Delhi, Chapter 18. Page no. 1053.

2. Newschaffer CJ, Falb MD, Gurney JG. National autism prevalence trends from United States special education data, Pediatrics. 2005; 115 (3): e 277-82.

3. Vaidya Yadavji Trikamji Acarya. Caraka Samhitā by Agniveśa. 2nd edition. Varanasi: Krishnadas Academy; 2000. p 223 (CS Ni 7/5)

4. Rudra A, Belmonte MK, Soni PK, Banerjee S, Mukerji S, Chakrabarti B. Prevalence of autism spectrum disorder and autistic symptoms in a school-based cohort of children in Kolkata, India. Autism Research. 2017 Oct;10(10):1597-605. 
5. Vaidya Yadavji Trikamji Acarya. Caraka Samhitā by Agniveśa. 2nd edition. Varanasi: Krishnadas Academy; 2000. p 223 (CS Ni 7/5)

6. Nordquist, N., Oreland, L. Serotonin, genetic variability, behaviour and Psychiat disorders - a review. Upsala Journal of Medical Sciences. 2010; 115(1): 2-10. http://doi.org/10.3109/03009730903573246

7. Esparham AE, Smith T, Belmont JM et al. Nutritional and Metabolic Biomarkers in Autism Spectrum Disorders: An Exploratory Study. Integrative Medicine: A Clinician's Journal. 2015; 14 (2): p 40-53

8. Chaste, P., \& Leboyer, M. (2012). Autism risk factors: genes, environment, and gene-environment interactions. Dialogues in Clinical Neuroscience. 14 (3): p 281-292.

9. Daniel K. Goyal and Jaleel A. Miyan. Neuro-Immune Abnormalities in Autism and their interaction with the environment: A Variable Insult Model for Autism. Front Endocrinol (Lausanne). Published online 2014 Mar 7. 2014; 5: 29. PMCID: PMC3945747 DOI: 10.3389/fendo.2014.00029

10. Philip J. Landrigan, Lippincott Williams, Wilkins. What causes autism? Exploring the environmental contribution. Wolters Kluwer Health. 2010; 10408703 DOI: 10.1097/MOP.0b013e328336eb9a

11. Nordquist, N., Oreland, L. Serotonin, genetic variability, behaviour and psychiatric disorders $-\mathrm{a}$ review. Upsala Journal of Medical Sciences. 2010; 115(1): 210. http://doi.org/10.3109/03009730903573246

12. Autism Spectrum Disorder. American Psychiatric Association. Diagnostic and Statistical Manual of mental disorders, 5th edition. Washington DC. 2013

13. Woods JJ, Wetherby AM. Early identification of and intervention for infants and toddlers who are at risk for autism spectrum disorder. Language, Speech, and Hearing Services in Schools. 2003.

14. Vaidya Yadavji Trikamji Acarya. Caraka Samhitā by Agniveśa. 2nd edition. Varanasi: Krishnadas Academy; 2000. p 289 (CS Sa 1/22-23)

15. Vinodkumar MV Dr Essential of Padārtha-Vijñāna. Cherpulassery. Perfect Publishers; 2014 Jul. p 141

16. Vaidya Yadavji Trikamji Acarya. Caraka Samhitā by Agniveśa. 2nd edition. Varanasi: Krishnadas Academy; 2000. p 223 (CS Ni 7/5)'

17. Vaidya Yadavji Trikamji Acarya. Caraka Samhitā by Agniveśa. 2nd edition. Varanasi: Krishnadas Academy; 2000. p 223 (CS Ni 7/7)

18. Agnivesha, Charaka, Dhridhabala, Charaka Samhita, Maharoga Adhyaya, Sutra Sthan, Chapter 20 Verse
11, edited by Pandit Kashinatha Shastri, Dr. Gorakha Natha Chaturvedi, Part 1, Varanasi: Chaukhambha Bharati Academy.;2009, p.399

19. Agnivesha. Unmada Chikitsitam. In: Yadavji Trikamji Acharya (ed.) Caraka Samhita. Varanasi; Chaukhambha Prakashan; 2007.467-474p.

\section{Source of Support: Nil \\ Conflict of Interest: None Declared}

How to cite this URL: Nithya A K \& Jithesh Chowta: A View Of Ayurveda On Autism Spectrum Disorders - A Conceptual Study. International Ayurvedic Medical Journal \{online\} $2021 \quad$ cited July 2021\} Available from: http://www.iamj.in/posts/images/upload/1419_1426.pdf 